\title{
Research on the Restrictive Factors and Countermeasures of Internationalization of Local Higher Education
}

\author{
Hong JI \\ Business School of Jiangxi Normal University, \\ Nanchang, China \\ jxsdjh@vip.sina.com
}

\author{
Ying SHI \\ Education School of Jiangxi Normal University, \\ Nanchang, China \\ 804370241@qq.com
}

\begin{abstract}
In the face of the internationalization of education, local colleges and universities can take the initiative to participate in the internationalization of higher education to achieve the priority to survive and develop. At present, in the process of internationalization of local colleges and universities, there are many problems such as the backwardness of education internationalization; the lack of internationalization of students' education, the weakness of international teachers, the low creative ability of the internationalization of education and lack of the campus internationalization atmosphere. We need to analyze the constraints of the internationalization of local higher education institutions, through setting up the concept of internationalization of education, improving the ratio of going abroad to study, strengthening the construction of teaching staff of internationalization and international exchanges and cooperation, to create an international atmosphere on campus to improve the level of internationalization of higher education.
\end{abstract}

Keywords-Local higher education; Internationalization of education; Restrictive factors; Countermeasures

\section{INTRODUCTION}

In the worldwide, with the trend of economic globalization is strengthening, the globalization of education has become an inevitable trend, especially at present, the international cooperation between institutions of higher education increase frequently, and the competition between them also becomes increasingly fierce, as the local colleges and universities with big number and small strength, how to seize the opportunity of the internationalization of education, to improve the education level of the local colleges and universities continually, has become the current hot topic in the field of higher education. Therefore, local universities need to fully realize the possibility and necessity of developing the internationalization of education, and broaden students' thinking, give full play to regional advantages, constantly improve their own reputation and comprehensive competitive strength.

\section{THE SIGNIFICANCE OF INTERNATIONALIZATION DEVELOPMENT OF LOCAL HigHER EDUCATION}

\section{A. The Needs of Local Colleges and Universities to Survive and Develop}

Local colleges and universities as an important part of higher education in China, playing a huge role in the promotion of regional economic development and progress of our country but due to the influence of geography, political, cultural, economic and other factors, the school resources, school idea, school quality, school location, the size of the school, and the influence of education of local colleges and universities that comparing with the domestic famous universities, there is still a certain gap, which restricts the long-term development of local colleges and universities to a great extent. Especially at present, the number of college students continued to decline, if local colleges and universities want to win the future survival and development, not only need to highlight the school characteristics, but also need draw support from the favorable opportunity of internationalization of education, and through the practice of a variety of international education, accumulating experience in education continually, and only in this way can local colleges and universities achieve better development.

\section{B. The Needs of Local Colleges and Universities to Expand Their Educational Space}

For a long time, the development of the local colleges are subject to regional restrictions, coupled with the impact of factors like weak overall strength, not high academic levels , the opportunities of local colleges and universities to participate in international academic exchange is relatively small, especially at present, the higher education is increasingly popular, a lot of local colleges and universities have gradually lost their opportunity to participate in international exchanges and cooperation, even the running space is compressing continually. But in the background of knowledge economy, information technology make progress and develop continually, which accelerate the process of internationalization of higher education, if local colleges and universities want to win a space, they must be combined with the practice of internationalization, localization and regionalization to promote its own school 
space, to enhance the cross cultural international view of students and teachers, and to achieve their own survival and the continuous expansion of development space.

\section{The Needs to Enhance Core Competitiveness}

If local colleges and universities want to improve their management level, and expand the influence at home and abroad, the most fundamental thing is to enhance their core competitiveness, in the information network era, the trend of international political pluralism and economic globalization is becoming more and more obvious, the internationalization of higher education has become an inevitable trend, which convenient the exchanges and cooperation of the international academic ,but also exacerbated the competition among colleges and universities.

\section{THE RESTRICTING FACTORS OF INTERNATIONALIZATION DEVELOPMENT OF LOCAL HIGHER EDUCATION}

At present, there are five main constraints in the internationalization of local higher education:

\section{A. The Concept of Internationalization of Education Lags Behind}

The concept of higher education internationalization development lags behind, mainly manifested in four aspects: the first is "sanctification", which is influenced by the "foreign things are better" consciousness, One-sided understanding of internationalization as "space science and technology, fiber communications" and other cutting-edge knowledge and technology incarnation, and is to play 985 project and the 211 Project universities duty, is the first student of the patent, and has little connection with teachers and students in local colleges and universities; the second is "isolation", considering the internationalization of education is the school's own thing, not to be promoted to the national and regional strategic level, which separates the political, economic and cultural links with the local government ;the third is "formalization", considering establish the International Exchange Office (Center), arrange the teacher several trips abroad, hire a few foreign teachers to teach students to study, and receive several overseas students is international, simply to meet the formalism, not focus on the formation of internationalization of university ethos and cultural atmosphere; the fourth is "simplification", internationalization is understood as internationalization of a particular profession or field, ignoring the internationalization should be involved in all areas of all walks of life, such as the international media, sports management, logistics, hotel management, airport management, real estate management, the car design and so on, advanced and learned knowledge and skills, all belong to the category of international education.

\section{B. The Lack of Students' Cognition of Education Internationalization}

On the one hand, students in local universities have subconsciously isolated themselves from the international tide, who are not care about other things beside study, or focus on the textbook knowledge, or bound to the teachers' teaching, engage in "research" in the laboratory, not macroscopically grasp the environment and the discipline frontier, and lack of international consciousness and international academic competitiveness, then form "consciousness of vacuum". On the other hand, one-sided understanding of "internationalization", the students or be too dependent, neglect the negative impact of internationalization, and sanctified the internationalization craze; or some students will feel skeptical of themself or the professional or school strength, active avoidance or give up the opportunity to connect with the world, then the students will enter "internationalization limbo"; what's more, some students are too idealistic about the strength of the country and the situation at home, refused to accept international advanced knowledge and culture, then forming a "closed" situation.

\section{Weak International Teachers}

Local colleges and universities that restricted from the location's degree of openness, educational philosophy, educational level, investment funds, and the internationalization level of cognitive ,the job opening exchanges of local colleges and universities started late, starting point was low, scale was small, content was simplex. The level of the teachers had a wide gap between the requirement of the internationalization, the internationalization consciousness of majority of teachers are not strong, and their teaching idea is behind, teaching content is outdated, teaching method is simplex, lack guidance and cultivation of students' international consciousness. It is difficult for them to cultivate new compound talent with international competitiveness, and to lead the trend of the times.

\section{The Innovation Ability of Education Internationalization is Lower}

The objective analysis shows that there are four advantages for local universities to carry out the internationalization of education. First, regional advantages. Local colleges and universities are generally located in relatively remote areas, but the location is often rich in natural, humane and tourist resources, and has a strong attraction to foreigners. It is of great value to carry out international work. Second is the brand advantage. In the practice of many years, local universities have formed their own brands, and should make good use of their own brand advantages in the process of foreign exchange and cooperation. Once the time is coinciding, we can take the initiative to attack, and vigorously develop the education of foreign students, come to foreign countries directly to open up educational markets. Third is talent advantage. Relative to the center of city and coastal city, the flow of talent in local universities is relatively slow; there are a number of academic leaders and experts in the full vigor of life, which can attract many foreign learners. Fourth is monopoly advantage. As a professional institution, there is often no similar institution to compete with each other in local areas. It should take advantages of being in a local monopoly and conducting international work. At present, local colleges and universities have not developed these four advantages well. They have not actively explored their own international innovation model, and their education internationalization creativity is not strong enough. 


\section{E. The Campus Internationalization Atmosphere is Not Strong}

The campus internationalization atmosphere is divided into two parts: macroscopic and microcosmic. Macroscopically, it represents the whole school's acceptance, tolerance and absorption of foreign advanced knowledge, technology and culture. On the micro level, through a variety of activities and organization of the school, cultivating students' global vision and global thinking mode, innovation ability and international competition ability systematically and all-round, make students familiar with international rules, and with higher international operation ability and management level, and make students familiar with a variety of Chinese and foreign culture, having good intercultural communication ability and the international exchange and cooperation ability etc. Local colleges and universities is still unable comprehensively cultivating students thinking and consciousness of internationalization, and developing overseas study and field practice extensively, and unable introduce foreign teachers and accept foreign students massively. The construction of campus internationalization atmosphere has a long way to go.

\section{THE COUNTERMEASURES OF INTERNATIONALIZATION DEVELOPMENT OF LOCAL HighER EDUCATION}

\section{A. Establish the Idea of Internationalization of Education}

Local university leaders and academic leaders should study and establish advanced concepts of international education, so as to correctly grasp the development situation and locate accurately. The "first in command project" should be implemented, and the internationalization development of each institute will be included in the assessment of the college. First, establishing assessment index system. Formulate a unified system of international work level evaluation; second, establishing a mechanism based on the internationalization of college development. The school places power under the various colleges and provides policy support, and the international exchange provides professional support and services to each institute; third, constructing a dynamic monitoring mechanism. Led by the international exchange and cooperation department to establish a dynamic monitoring mechanism, each year evaluate and publish the progress of the project indicators regularly; fourth, establishing reward and punishment mechanism. The school carries on the material reward to the internationalization high level institute, and counts in the appraisal mechanism of leadership.

\section{B. To Improve the Rate of Study Abroad}

Local colleges and universities should make clear the main responsibilities of each subordinate institute in the course of students studying in the abroad, and to ensure that the pressure transfer in place, the responsibility to put in place; then universities should enlarge the publicize strength of student to study abroad, to create a strong learning atmosphere of going abroad, to provide information consultation and guidance service for the students to study abroad. Besides, universities should strengthen cooperation with domestic and foreign educational institutions, for provide more options of students going abroad to learning; then introducing foreign language exam training institutions, to help students improve their English level, and eliminate their language barriers of studying abroad; finally, universities can establish the International communication fund of students, support students to go to abroad to studying, and rewarding institute with high rate of studying abroad.

\section{Strengthen the Construction of International Teachers}

At present, an important factor in the evaluation of the international level and even the academic level of a university is the internationalization of the faculty. The establishment of an international team of teachers is the first requirement for the internationalization of schools. The main contents are as follows: firstly, teachers should be encouraged to go abroad for further study to optimize the international structure of the teachers' team. Given the high cost of studying abroad, colleges and universities should formulate relevant policies to encourage and help college teachers to go abroad to visit or study, providing convenience for teachers to study abroad (postdoctoral and visiting scholars etc.), rather than obstacles. Secondly, colleges and universities should make good use of international higher education resources, vigorously introduce overseas returnees, adopt flexible methods to recruit famous foreign teachers and carry out international academic exchange of teachers. Although due to various constraints, the introduction of high-end scholars of local colleges has not the advantage like the well-known university, they also can actively seek the support of local government, establishing effective management system, through the school's abroad teacher recommendation, cooperative education, student resources and other channels to introduce high-end international talents. Again, the university should focus on supporting and training teachers with international vision and international reputation in the field of professional, and the university should encourage teachers to teach students with his professional cutting-edge knowledge, to exercise and cultivate students' innovation consciousness and quality of internationalization.

\section{Strengthen International Exchanges and Cooperation}

It is an effective way to promote international reputation of higher education by working with well-known international organizations. By joining the international education organization, academic and student exchanges and cooperation between the colleges and within the organization can be set up, colleges can explore the progress and development of scientific research, strengthen mutual exchanges, learn from each other's strengths, it is very helpful to enhance the university's international competitiveness and innovation ability. At present, the education organization like this has big number, such as East Asia Alliance Research University (AEARU), University of the Pacific (APRU), the global alliance for Sustainable Development Alliance (AGS), twenty-first Century University Alliance, the international alliance of research universities (IARU) etc. Through cooperation between Chinese and foreign governments, establishing cultural agreements and other cooperation projects, the intelligent, financial and other aspects can be guaranteed, so as to enhance the gradation and level of internationalization. 


\section{E. Create an International Campus Atmosphere}

The influence of the campus atmosphere on the students is imperceptible, smooth and silent. This influence is always the most effective and impressive one. Local universities should develop a long-term strategy to fight a protracted war, first from the bilingual teaching, and gradually carry out the transition to the English teaching, can start from the pilots of school several characteristic professional, gradually to the all school, the ultimate aim is to train the students to have the ability and confidence to go to the world, and to participate in the international activities.

\section{CONCLUSION}

Although in the aspects of the internationalization of education, there still has a large gap between Chinese local colleges and famous universities at home and abroad, the key part of local university campus construction, equipment and other aspects have been more perfect, some of the high level professional which have a certain strength in scientific research and teaching level, has the condition and foundation of internationalization of school. By setting up the internationalization of the educational philosophy, encouraging and helping teachers and students to carry out internationalization activities, strengthening international exchanges and cooperation, cultivating internationalized campus atmosphere and other measures, can make it possible for college students to contact the internationalization of education, and to offer support of cultivating more talents with international communication skills, and to provide protection for the enhancement of China's competitiveness in the world.

\section{REFERENCES}

[1] Li Bo, Song Fangfang. Practice and exploration of internationalization of local higher education institutions based on fieldwork in two local universities in Shandong [J]. Journal of Linyi University, 2016 (4): 107 112

[2] Weng Mingli. Barriers and Countermeasures of internationalization of local higher education [J]. Industry and Science and Technology Forum, 2015 (24): 113-114

[3] Wang Bin, Jiang Bei, Wang Qi. Research on the internationalization of education in local universities [J]. China Adult Education, 2011 (1): 7678

[4] Li Lingjun, Duan Junfei, Gong Li, Chen Zhaoyong, Zhu Huali. On the internationalization of education in local colleges and universities [J]. science and technology innovation report, 2015 (27): 216 - 217

[5] Wang Qingshi, Liu Wei. Problems and Countermeasures of internationalization of higher education in China [J]. modern education management, 2009 (5): 24 - 27

[6] Li Zhe. On the core competence of local comprehensive universities. [M]. Beijing: Education Press, 2015 